\title{
Discovery of a possible role of asprosin in ovarian follicular function
}

\author{
Excel Rio S Maylem¹, Leon J Spicer ${ }^{1}$, Isadora Batalha ${ }^{2}$ and Luis F Schutz ${ }^{2}$ \\ 'Department of Animal and Food Sciences, Oklahoma State University, Stillwater, Oklahoma, USA \\ 2Department of Agriculture, Veterinary, and Rangeland Sciences, University of Nevada, Reno, Nevada, USA
}

Correspondence should be addressed to L J Spicer: Leon.spicer@okstate.edu

\begin{abstract}
Asprosin is a novel fasting-induced protein encoded by fibrillin-1 (FBN1) gene, produced when FBN1 is cleaved by the enzyme furin, and is associated with insulin resistance and polycystic ovarian syndrome in humans. To characterize mRNA abundance of FBN1, FURIN, and the presumed asprosin receptor, olfactory receptor family 4 subfamily $\mathrm{M}$ member 1 (OR4M1) in granulosa (GC) and theca cells (TC), and identify hormones regulating FBN1 mRNA expression, GC and TC from small (1-5 mm; SM) and large (>8 mm; LG) follicles were collected from ovaries of heifers obtained at an abattoir and used for real-time PCR gene expression analysis or in vitro evaluation of hormone regulation and asprosin effects. SMTC had 151 -fold greater $(P<0.05)$ FBN1 mRNA abundance than SMGC, and LGTC had 50-fold greater FBN1 mRNA than LGGC. In contrast, OR4M1 mRNA was 81-fold greater in SMGC than LGGC and did not differ from SMTC, but LGTC had 9-fold greater OR4M1 mRNA than LGGC. FURIN mRNA was 2.6-fold greater in SMTC than SMGC, but did not differ among follicular sizes. In cultured TC, leptin, insulin, LH, IGF1 and steroids did not affect FBN1 mRNA, but TGFB1 increased $(P<0.05) F B N 1$ mRNA by 2.2-fold; EGF and FGFs increased FBN1 mRNA by 1.3- to 1.5-fold. Asprosin enhanced LH-induced TC androstenedione production, reduced IGF1-induced TC proliferation, and had no effect on progesterone production. Developmental regulation of $F B N 1$, FURIN and OR4M1 along with direct effects of asprosin on TC suggests that asprosin may be a novel regulator of ovarian follicular function.
\end{abstract}

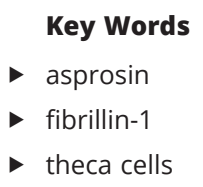

Journal of Molecular

Endocrinology

(2021) 66, 35-44

\section{Introduction}

Asprosin is a recently discovered protein, released by white adipose tissue that targets the liver activating the G-protein-cAMP-PKA pathway to release glucose in the blood stream (Duerrschmid et al. 2017). Both asprosin and fibrillin are encoded by FBN1 gene and synthesized together as a pro-protein, and subsequently separated by the enzyme furin at the C-terminal end of FBN1 (Romere et al. 2016). Asprosin increases in the blood with fasting and decreases after feeding linking asprosin to glucose metabolism, obesity, insulin resistance and metabolic disorders like type II diabetes (Romere et al. 2016, Duerrschmid et al. 2017, Li et al. 2019, Wang et al. 2019) and polycystic ovarian syndrome (PCOS) (Li et al. 2018, Alan et al. 2019). Interestingly, oocyte-specific deletion of furin leads to female infertility by causing early secondary follicle arrest in mice (Meng et al. 2017) but whether asprosin has direct effects on ovarian function is unknown. 
The family of fibrillin proteins include the TGF $\beta$ binding proteins as part of the extracellular matrix that are localized and expressed in different parts of the ovary and follicle (Rodgers et al. 2003, Prodoehl et al. 2009). Specifically, Prodoehl et al. (2009) found that FBN1 protein was localized in the outer regions of tunica albuginea and in the stroma, appearing as fibrillar structures which forms microfibrils in connective tissues for structure and mechanical stability. In larger antral follicles, FBN1 protein is localized closest to the epithelial granulosa layers and highly expressed in most of the theca interna layer (Prodoehl et al. 2009). The theca interna plays an essential role in forming the structure of an ovarian follicle, delivering nutrients to the granulosa cell (GC) layer, cumulus cells and oocyte and by releasing endocrine and paracrine factors (Tajima et al. 2007, Young \& McNeilly 2010, Richards et al. 2018). In addition to FBN1, the theca layer of growing follicles is composed of extracellular matrix factors including collagen, laminin, fibronectin, and proteoglycans (Rodgers et al. 2003, Richards et al. 2018). GC and theca cell (TC) communication is important in regulating cell proliferation and differentiation, steroidogenesis and overall ovarian function (Yada et al. 1999, Tajima et al. 2007, Hsueh et al. 2015). Theca factors modulate the hormone producing capacity of GC biphasically during follicular maturation, while GC factors promote both differentiation and growth of TC during follicular development (Yada et al. 1999, Liu et al. 2019). Although, both cell types are working together, TC play a more crucial role in diseases like PCOS due to excessive production of androgens (Rosenfield \& Ehrmann 2016). Recently, it was reported that elevated plasma asprosin levels in women are associated with increased risk for developing PCOS and correlated positively with free androgen index (Alan et al. 2019) and total testosterone in obese PCOS women (Li et al. 2018).

In mice, the asprosin receptor, olfactory receptor (Olfr734) has been identified recently in different tissues including liver, kidney and testis, but has not been studied in ovaries. In a knockout mouse model, it was observed that hepatic Olfr734 protein binds to asprosin to promote hepatic gluconeogenesis (Li et al. 2019). Moreover, mice that are Olfr734-deficient were observed to have attenuated cAMP levels and hepatic glucose production and increased insulin sensitivity, and when fasted and given a high-fat diet, mice with knockout Olfr 734 produced less glucose (Li et al. 2019). OR4M1, a homolog of Olfr734, was also highly expressed in the testis and olfactory bulb but moderately expressed in liver tissue, both of these asprosin receptors were recently identified to promote hepatic gluconeogenesis and negatively regulate insulin sensitivity (Li et al. 2019, Hoffmann et al. 2020). Whether OR4M1 mRNA is expressed in ovarian cells such as GC or TC is unknown.

With asprosin playing a significant role in insulin resistance and perhaps PCOS, and that FBN1 is highly expressed in TC, there is a possibility for a gene-protein interaction in ovarian cells. Thus, it was decided to study FBN1 and asprosin relationship in ovarian function. Specifically, the present study aimed to characterize FBN1, FURIN and OR4M1 mRNA abundance in TC and GC in small and large follicles, and evaluate the possible hormone regulators for expression of FBN1 mRNA in TC. The effects of asprosin on steroid production and proliferation of TC were also evaluated.

\section{Materials and methods}

\section{Reagents and hormones}

Reagents used for cell culture were: Dulbecco's modified Eagle medium (DMEM), Ham's (F12), insulin, enzymes, antibiotics, TRI reagent, estradiol (E2), dihydrotestosterone (DHT), progesterone (P4), leptin, and androstenedione (A4) were obtained from Sigma-Aldrich Co.; purified ovine FSH (FSH activity, $15 \times$ NIH-FSH-S1 U/mg) and ovine LH (LH activity, $2.3 \times$ NIH-LH-S1 U/mg) from the National Hormone and Peptide Program (Torrance, CA); carrierfree recombinant human IGF1, fibroblast growth factor (FGF2 and FGF9), EGF, transforming growth factor-beta 1 (TGFB1), and wingless-type MMTV integration site family member 3A (WNT3A) from R\&D Systems (Minneapolis, $\mathrm{MN}$ ); testosterone from Steraloids (Wilton, NH); recombinant human asprosin from Biologics Inc. (Cary, NC); and fetal calf serum (FCS) from Atlanta Biologicals (Flowery Branch, GA).

The reagents used for RIA were ${ }^{[125 I]}$ iodo-P4 (MP Biomedicals, Irvine, CA) and anti-P4 rabbit antiserum (X-16) were provided by Dr P. Natashima Rao (Southwestern Foundation for Research Education, San Antonio, TX), normal rabbit serum (Equitech, Kerville, TX) and Androstenedione Double Antibody - 125I RIA Kit (MP Biomedicals).

\section{Granulosa and theca cell collection}

The first experiment was designed to determine if the abundance of FBN1, FURIN, and OR4M1 mRNA in GC and TC changes during follicle growth. Ovaries from nonpregnant beef heifers were collected at an abattoir where 
humane slaughter practices were followed, according to USDA guidelines and transported to the lab on ice in antibiotic saline $(0.9 \%$ saline solution with $1 \%$ penicillinstreptomycin) as previously described (Langhout et al. 1991, Schreiber et al. 2012). For large-follicle (LG; 8-20 $\mathrm{mm}$ ) GC and TC, each of 6 or 7 samples was collected from one LG healthy follicle from one ovary as previously described (Zhang et al. 2017). For small follicle (SM; 1-5 mm) GC and TC, each sample had pooled cells from 3 to 5 small follicles from one ovary. Each cell type had 6 or 7 samples collected from at least three animals. These fresh cells were lysed in TRI reagent and RNA was extracted as described subsequently.

Ovaries from beef heifers were collected at an abattoir as described earlier, and follicular fluid was aspirated from SM follicles (1-5 mm) and LG follicles (8-20 $\mathrm{mm}$ ) to collect the GC. Then follicles were dissected to isolate TC via enzymatic digestion (i.e. collagenase, DNase, protease, and hyaluronidase) and filtration as previously described (Stewart et al. 1995, Schreiber et al. 2012, Schütz et al. 2016). GC and TCs were suspended in a serum-free medium (1:1 DMEM/F12 supplemented with $2.0 \mathrm{mM}$ glutamine, $0.12 \mathrm{mM}$ gentamycin, $38.5 \mathrm{mM}$ sodium bicarbonate, $1.25 \mathrm{mg} / \mathrm{mL}$ collagenase and $0.5 \mathrm{mg} / \mathrm{mL}$ deoxyribonuclease). Prior to cell culture, viability of cells was measured by trypan blue exclusion method, and approximately $2.0 \times 10^{5}$ viable cells were plated on 24-well culture plates with each well containing $1 \mathrm{~mL}$ of culture medium with $10 \%$ of FCS. This culture system has been shown to support the growth of TC that are responsive to LH and IGF1 (Stewart et al. 1995, Schreiber \& Spicer 2012). Culture plates were incubated in a humidified incubator with $5 \% \mathrm{CO}_{2}$ and $95 \%$ air at $38.5^{\circ} \mathrm{C}$ for $48 \mathrm{~h}$ with a medium change every $24 \mathrm{~h}$. Cells were then treated for another $24 \mathrm{~h}$ or $48 \mathrm{~h}$, with medium change every $24 \mathrm{~h}$ using serum-free medium. Treatments were applied for $24 \mathrm{~h}$ or $48 \mathrm{~h}$ depending on experimental design, and cells were harvested for either RNA isolation or cell counting. Medium was collected for steroid RIA.

\section{RNA extraction and quantitative PCR}

Cell culture medium was aspirated, replaced with $250 \mu \mathrm{L}$ of TRI reagent, and wells were scraped to collect the cells. Samples were stored at $-80^{\circ} \mathrm{C}$ until RNA was extracted as described previously (Spicer et al. 2006, Zhang et al. 2017). Briefly, RNA from cell lysates were isolated using TRI reagent protocol and Phase Lock Gel Heavy tubes (5 Prime Inc., Germantown, MD). Each RNA sample was solubilized in DEPC water and measured quantitatively using NanoDrop ND-1000 spectrophotometer (NanoDrop Technologies, Inc., Wilmington, DE) at $260 \mathrm{~nm}$ and stored at $-80^{\circ} \mathrm{C}$ for future use.

The primers and probes for $F B N 1$, asprosin receptor (OR4M1/Olfr734) and FURIN were designed using IDT technologies (Coralville, IA). The FBN1 forward primer: 5'-GTACGAACACAGTCAGCAGTTA-3'; reverse primer: 5'-TATCCTGGGCGGACATCTAT-3'; probe: 5'-/56-FAM/ ACACCTCTC/ZEN/CAGACGGTACCAGAT/3IAbkFQ/-3'. While, for the OR4M1 primers and probe, a multiple sequence alignment was first done with the Olfr734 sequence as identified in mice and the OR4M1 as the homolog for the bovine species. After getting the sequences aligned, primers were designed and the forward primer: 5'-TGATGGCCTTTGACCGATATG-3'; reverse primer: 5'-CAGGAGAAAGCCACCAGAATAC-3'; probe: 5'-/56-FAM/ACCATCATG/ZEN/AATCGACGTCTC TGCT/3IABkFQ-3'. The forward primer for FURIN was 5'-CGTGGCATTGTGGTCTCTATC-3'; reverse primer: 5'-CAGGGTCCTGATCATTGACATC-3' and probe: 5'-/56-FAM/AGAAGAACC/ZEN/ACCCAGACTTGGCAG/ 3IABkFQ/-3'. Primer sequences were submitted to BLAST (http://blast.ncbi.nlm.nih.gov/Blast.cgi) to check for highly similar sequences, to ensure primer and probe specificity, and to determine if there were non-homologous regions coding for other genes. The target gene expression was normalized using 18S rRNA (Taqman rRNA Control Reagent, Applied Biosystems Inc.). The housekeeping gene, 18S rRNA was selected because previous studies reported it to be a stable gene over a variety of treatments (Schmittgen \& Zakrajsek 2000, Sekar et al. 2000, Tsuji et al. 2002, Voge et al. 2004, Zhang et al. 2017). The quantitative PCR used a one-step method and a CFX96 Touch RealTime PCR Detection System (BioRad) as follows: $10 \mathrm{~min}$ at $50^{\circ} \mathrm{C}$ for RT, $5 \mathrm{~min}$ at $95^{\circ} \mathrm{C}$ for denaturation, 50 cycles of $10 \mathrm{~s}$ at $95^{\circ} \mathrm{C}$ for annealing and $30 \mathrm{~s}$ at $60.4^{\circ} \mathrm{C}$ for extension. Relative quantities of the genes were expressed as $2^{-\Delta \Delta \mathrm{Ct}}$ based on the relative comparative threshold values (Ct) as previously described (Dentis et al. 2017, Morrell et al. 2020). Briefly, the $\Delta$ Ct was calculated by subtracting the Ct of the 18S rRNA to the Ct of the target gene, followed by subtracting the highest $\Delta \mathrm{Ct}$ from all other $\Delta \mathrm{Ct}$ values to obtain the $\Delta \Delta \mathrm{Ct}$. The fold change of mRNA abundance for all the target genes were calculated and expressed as fold of control values.

\section{Radioimmunoassay (RIA)}

Medium samples from the culture plates were collected and stored at $-20^{\circ} \mathrm{C}$ for future RIA. For P4, a double 
antibody RIA was conducted as previously described (Langhout et al. 1991, Spicer et al. 2006). For the A4 RIA, an Androstenedione Double Antibody - ${ }^{125 I}$ RIA Kit was used following the manufacturer's protocol and as previously described (Stewart et al. 1995, Pizzo et al. 2015). Intra- and inter-assay coefficients of variation were 7.7 and $6.6 \%$, respectively, for the P4 RIA, and 9.4 and $10.2 \%$, respectively, for the A4 RIA.

\section{Cell counting}

Numbers of TC were determined using a Coulter counter (Model Z2; Beckman Coulter Inc., Hialeah, FL) as previously described (Spicer et al. 2006, Pizzo et al. 2016). Initially, wells were exposed to $0.5 \mathrm{~mL}$ of trypsin $(0.25 \%$ $(\mathrm{w} / \mathrm{v})$ in $0.5 \mathrm{M} \mathrm{NaCl})$ for $20 \mathrm{~min}$ at $37^{\circ} \mathrm{C}$, then cells were scraped from each well, and were disrupted via repetitive pipetting back and forth through a $500 \mu \mathrm{L}$ pipette tip, and diluted in 1:10 at $0.5 \mathrm{M} \mathrm{NaCl}$. Cell suspensions were then counted and values were expressed as cells per well. Intraassay coefficient of variation averaged $8.4 \%$.

\section{Experimental design}

Experiment 1 was an in vivo study conducted to determine if FBN1, FURIN, and OR4M1 mRNA expression differs in GC and TC of small and large follicles. Cells were isolated from various sized follicles and RNA was extracted as described earlier.

Theca cells were selected for Experiments 2-5 because FBN1 mRNA levels were found to be several fold greater in TC vs GC of Experiment 1. Experiment 2 was conducted to test the effect of steroid hormones on FBN1 mRNA abundance in LG-follicle TC collected in vitro. Cells were prepared as described earlier and cultured for $48 \mathrm{~h}$ in 10\% FCS supplemented medium, washed, and then treated for $24 \mathrm{~h}$ in serum-free medium containing P4 (300 ng/mL), E2 (300 ng/mL), A4 (300 ng/mL) and DHT (300 ng/mL). Doses of steroids were based on previous studies (Spicer 2005, Zhang et al. 2017).

Experiments 3-5 were conducted to evaluate the effect of various growth factors and metabolic hormones on FBN1 mRNA abundance in LG-follicle TC in vitro. Cells were cultured as described in Experiment 2 for $48 \mathrm{~h}$ in $10 \%$ FCS, washed, and treated with $300 \mathrm{ng} / \mathrm{mL}$ of P4, E2, A4 and DHT for $24 \mathrm{~h}$ in a serum-free medium. For Experiment 3 , treatments used were leptin (Lep; $100 \mathrm{ng} / \mathrm{mL}$ ), WNT3A (300 ng/mL), insulin (Ins; $100 \mathrm{ng} / \mathrm{mL})$, TGFB1 (30 ng/mL) and leptin-insulin combination (Lep-Ins). For Experiment 4, cells were treated with $30 \mathrm{ng} / \mathrm{mL}$ of EGF, FGF2 and FGF9.
For Experiment 5, treatments were LH (30 ng/mL) and IGF1 (30 ng/mL). Doses of hormones were based on the results from previous studies (Spicer \& Stewart 1996, Spicer 2005, Schreiber et al. 2012).

Experiment 6 was conducted to evaluate the effect of asprosin (200 $\mathrm{ng} / \mathrm{mL}$ ) treatment on cell proliferation and steroid production of TC treated with LH $(30 \mathrm{ng} / \mathrm{mL})$, IGF1 (30 ng/mL) and LH+ IGF1 in vitro. Cells were cultured for $48 \mathrm{~h}$ in 10\% FCS, washed, and treatments applied for another $48 \mathrm{~h}$ in serum-free medium. Medium was changed every $24 \mathrm{~h}$. Doses of LH and IGF1 were based on previous studies (Stewart et al. 1995, Spicer 2005). Dose of asprosin was selected to represent the higher end of concentrations reported in systemic blood of women (Romere et al. 2016, Wang et al. 2018) and mice (Romere et al. 2016).

\section{Statistics}

In Experiment 1, data for mRNA abundance of FBN1, FURIN and OR4M1 gene in different cell types (GC and TC) from SM and LG follicles were analyzed with general linear models procedure of SAS using $2 \times 2$ factorial ANOVA (version 9.4, SAS Institute Inc., Cary, NC). In Experiments 2-5, FBN1 mRNA abundance data were analyzed using oneway ANOVA. In Experiment 6, data for the effects of asprosin on cell proliferation and steroidogenesis were analyzed using $2 \times 2 \times 2$ factorial ANOVA. If necessary, values were transformed to natural $\log (\mathrm{x}+1)$ to ensure homogeneity of variance. Data were presented as either individual data points or means \pm s.E.M. Mean differences were assessed using Fisher's protected least significant differences test, if significant treatment effects in ANOVA were detected. Differences among groups or treatments were considered significant at $P<0.05$ and a trend at $0.05<P<0.10$. For the in vitro experiments (Experiments 2-6), three different pools were used as experimental (i.e. biological) replicates; replicate was included in the statistical model.

\section{Results}

\section{Experiment 1: Determination of FBN1, FURIN and OR4M1 mRNA abundance in GC and TC of small and large follicles}

All data have been included in the analyses. A significant follicle size $\times$ cell type interaction influenced FBN1 mRNA abundance such that in both SM and LG follicles, FBN1 mRNA abundance was greater $(P<0.05)$ in TC than GC (Fig. 1A). SMTC had 152-fold greater $(P<0.05)$ abundance of FBN1 mRNA than SMGC, while LGTC had 50-fold greater 


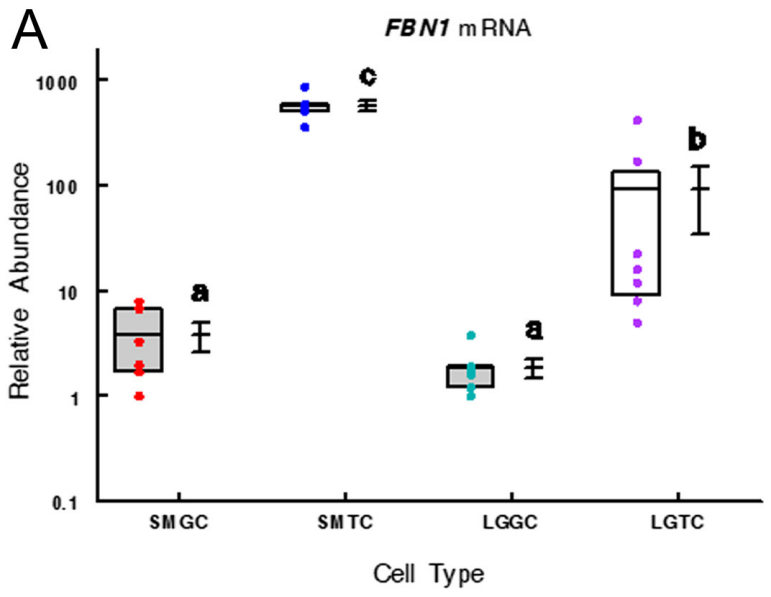

B

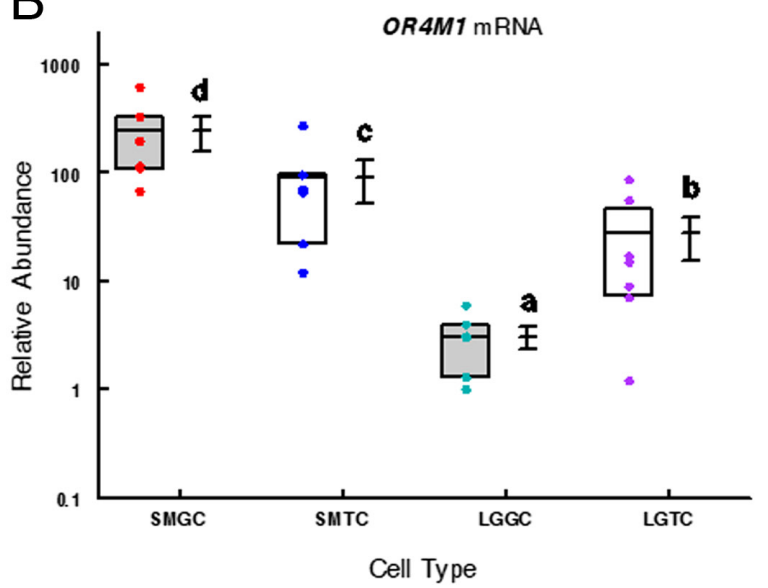

C

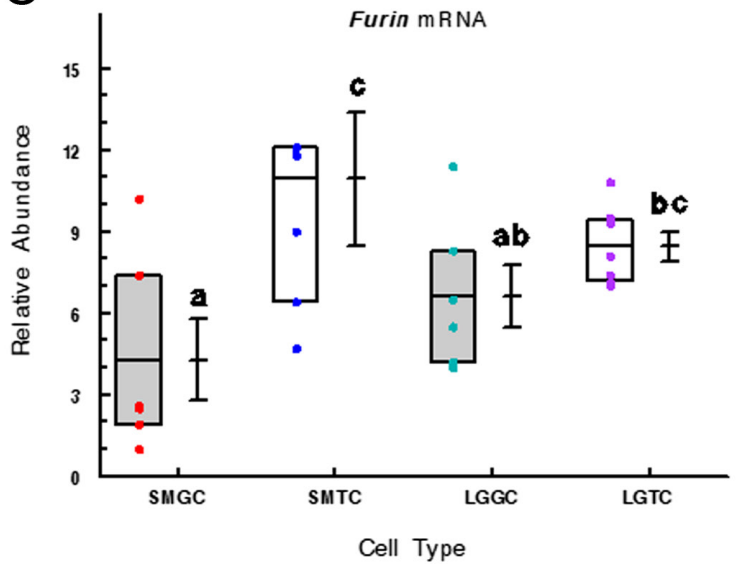

Figure 1

Changes in FBN1, OR4M1 and FURIN mRNA during follicular development (Experiment 1). Panel A: FBN1 mRNA abundance in granulosa (GC) and theca (TC) cells from small (SM) and large (LG) follicles. Means \pm S.E.M. without a common letter differ $(P<0.05)$; note log scale. Panel B: OR4M1 mRNA abundance in GC and TC from SM and LG follicles. Means \pm S.E.M. without a common letter differ $(P<0.06)$; note log scale. Panel C: FURIN mRNA abundance in GC and TC from SM and LG follicles. Means \pm S.E.M. without a common letter differ $(P<0.10)$. For all panels, means represent $n=6-7$. A full color version of this figure is available at https://doi. org/10.1530/JME-20-0218.
$(P<0.05)$ FBN1 mRNA than LGGC. SMTC had 6-fold greater $(P<0.05)$ abundance of FBN1 mRNA than LGTC.

A significant follicle size $\times$ cell type interaction influenced OR4M1 mRNA such that OR4M1 mRNA abundance was 81 -fold greater $(P<0.05)$ in SMGC than LGGC, and tended to be greater than in SMTC $(P<0.06$; Fig. 1B). LGTC had 9-fold greater $(P<0.05)$ OR4M1 mRNA abundance than LGGC.

Follicle size $\times$ cell type interaction tended to influence $(P<0.10)$ FURIN mRNA abundance whereas cell type $(P<0.01)$ but not size $(P>0.10)$ influenced FURIN mRNA abundance such that TC had 1.8 -fold greater $(P<0.05)$ FURIN mRNA abundance than GC. Specifically, FURIN mRNA abundance was greatest in SM and LG follicle TC and least in SMGC $(P<0.05$; Fig. 1C).

\section{Experiments 2-5: effect of hormones on FBN1 mRNA abundance in TC in vitro}

In Experiment 2, treatment of E2, A4, DHT and P4 did not alter FBN1 mRNA abundance in TC (Fig. 2; $P>0.05$ ). In Experiment 3, WNT3A, insulin, leptin and leptininsulin combination did not affect $(P>0.05) F B N 1$ mRNA abundance in TC compared with controls (Fig. 3), whereas TGFB1 stimulated $(P<0.05)$ FBN1 mRNA abundance by 2.23-fold. In Experiment 4, FGF2, FGF9 and EGF caused 1.33- to 1.52-fold increases (Fig. $4 ; P<0.05$ ) in TC FBN1 mRNA abundance. In Experiment 5, LH or IGF1 treatment

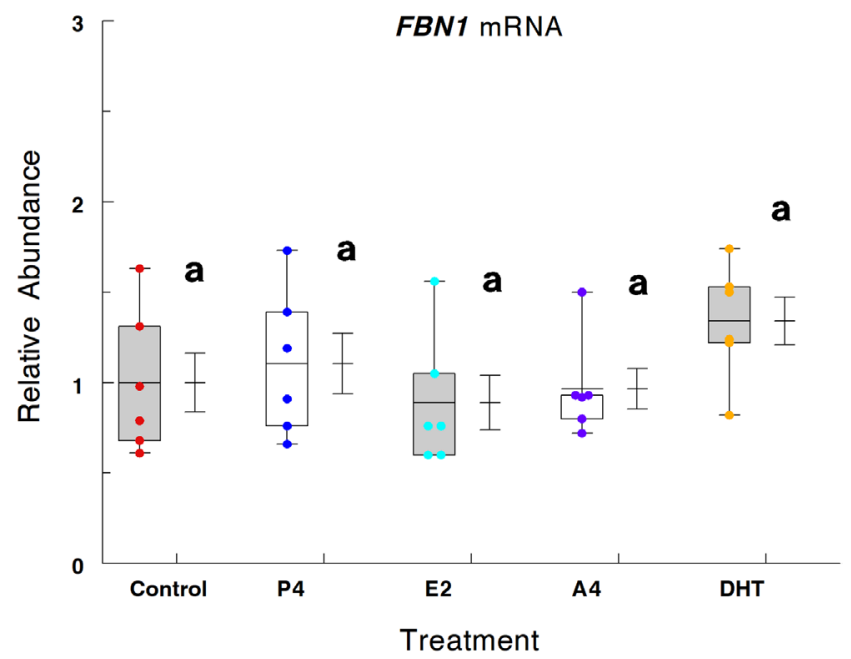

Figure 2

FBN1 mRNA abundance in steroid treated large theca cells (Experiment 2). $\mathrm{E} 2$, estradiol; $\mathrm{A} 4$, androstenedione; $\mathrm{DHT}$, dihydrotestosterone; $\mathrm{P} 4$, progesterone. Means \pm S.E.M. without a common letter differ $(P<0.05)$, and represent $n=6$ for each mean; no significant treatment effect was observed. A full color version of this figure is available at https://doi. org/10.1530/JME-20-0218. 


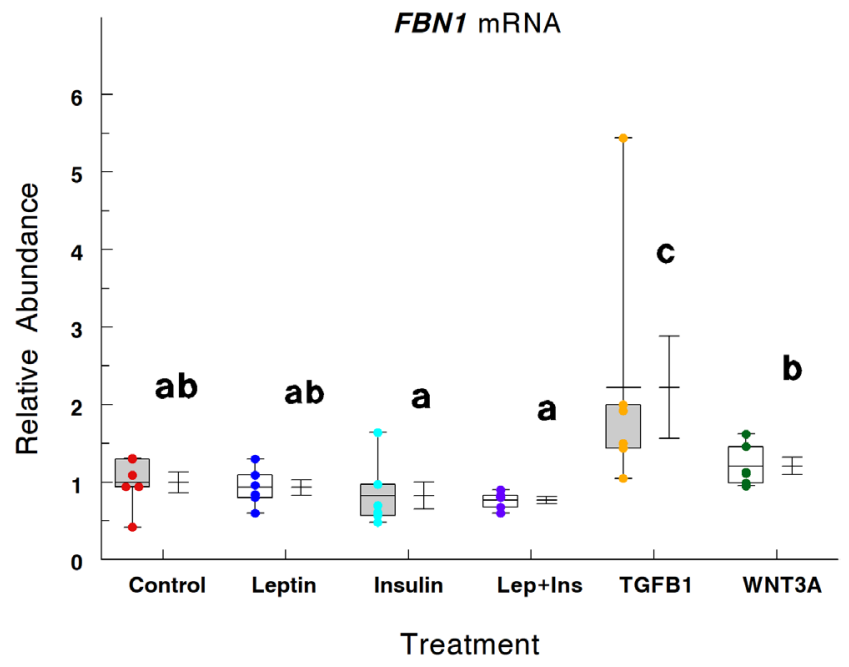

Figure 3

TGFB1 induced FBN1 mRNA abundance in theca cells (Experiment 3). TGFB1, transforming growth factor beta 1 ; WNT3A, wingless type 3A; Lep + Ins, leptin + insulin. Means \pm S.E.M. without a common letter differ $(P<0.05)$, and represent $n=6$ for each mean. A full color version of this figure is available at https://doi.org/10.1530/JME-20-0218.

had no significant effect (controls $=1.0 \pm 0.3, \mathrm{LH}=1.5 \pm 0.2$, IGF1 $=1.0 \pm 0.3, n=6$ ) on FBN1 mRNA abundance.

\section{Experiment 6: The role of asprosin in cell proliferation and steroidogenesis in TC}

Main effects on cell numbers included asprosin $(P<0.05)$, LH $\times$ IGF1 interaction $(P<0.001)$ and asprosin $\times$ IGF1

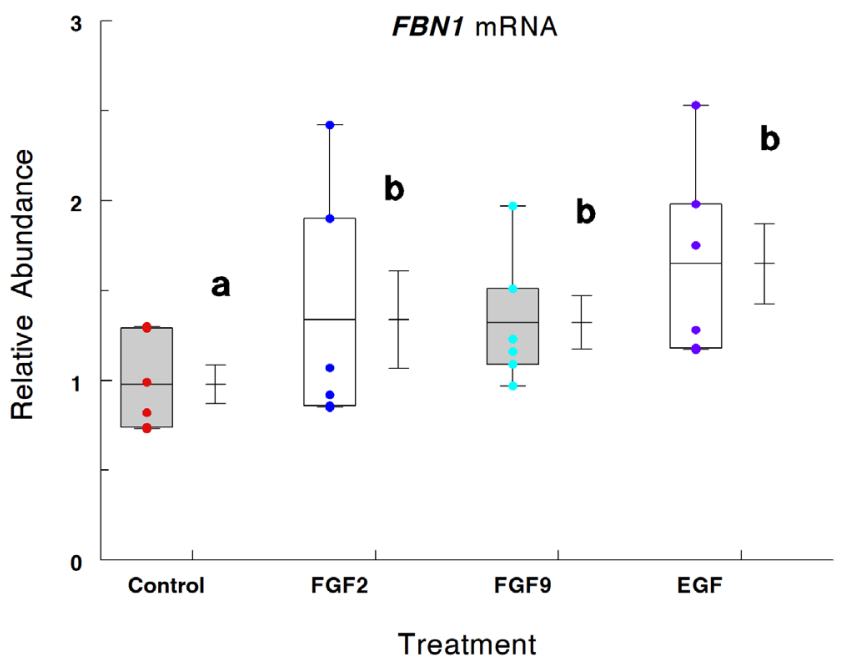

Figure 4

Stimulatory effects of EGF, FGF2 and FGF9 on FBN1 mRNA abundance in theca cells (Experiment 4). EGF, epidermal growth factor; FGF, fibroblast growth factor. Means \pm S.E.M. without a common letter differ $(P<0.05)$, and represent $n=6$ for each mean. A full color version of this figure is available at https://doi.org/10.1530/JME-20-0218.

(c) 2021 Society for Endocrinology Published by Bioscientifica Ltd. Printed in Great Britain interaction $(P<0.11)$. Alone, IGF1 $(P<0.05)$ increased TC numbers by $30 \%$, whereas LH alone tended $(P<0.08)$ to increase TC numbers (Fig. 5). Asprosin treatment alone had no effect on TC numbers but inhibited $(P<0.05)$ the IGF1-induced TC numbers by $11 \%$ in the absence of $\mathrm{LH}$, and tended $(P<0.07)$ to decrease TC numbers in the presence of IGF1 plus LH (Fig. 5).

Main effects on P4 production included LH, IGF1 and LH $\times$ IGF1 interaction $(\mathrm{P}<0.01)$. Asprosin or its interaction with LH or IGF1 had no significant effect on P4 production. Treatments of either IGF1 or LH alone increased $\mathrm{P} 4$ production by 2 - to 4 -fold above controls, whereas combined treatment of LH and IGF1 further increased $(P<0.05) \mathrm{P} 4$ production by 3 - to 5 -fold above either treatment alone (Fig. 6A). However, asprosin had no effect on these responses $(P>0.10)$.

Main effects on A4 production included LH $(P<0.01)$, IGF1 $(\mathrm{P}<0.01)$, LH $\times$ IGF1 interaction $(P<0.01)$, and asprosin $\times$ LH interaction $(P<0.08)$. Alone, LH and IGF1 increased A4 production by 5.1 - and 1.54 -fold, respectively $(P<0.05)$; combined, LH and IGF1 increased A4 production by 5.5- to 18 -fold above either treatment alone (Fig. 6B). Asprosin increased $(P<0.05)$ A4 production by $26 \%$ in $\mathrm{LH}$ treated cells (Fig. 6B), but asprosin had no effect $(P>0.10)$ on IGF1 and LH+IGF1 induced A4 production.

\section{Discussion}

This research is one of the first to elucidate the regulation of $F B N 1$ gene expression and the possible role of its protein

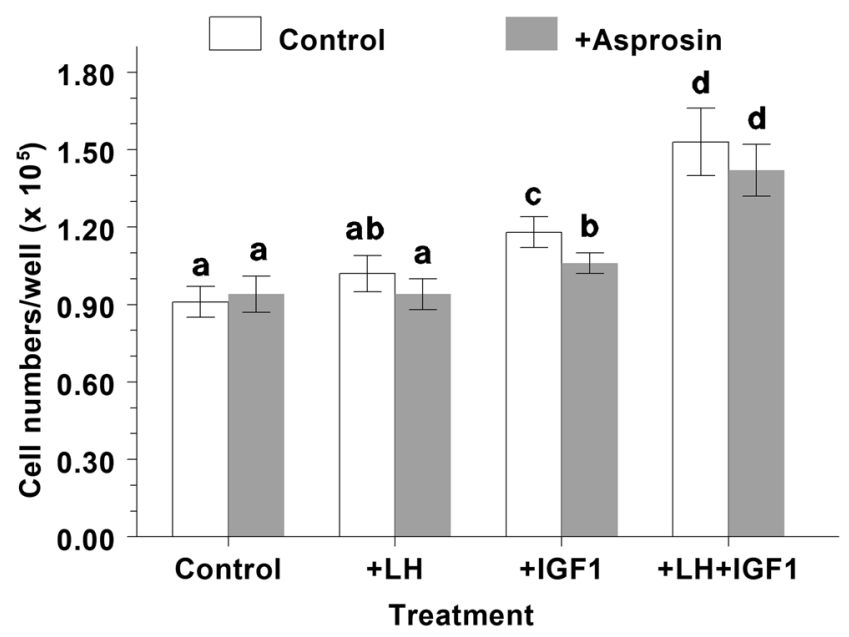

Figure 5

Effect of asprosin (200 $\mathrm{ng} / \mathrm{mL}$ ) on theca cell (TC) proliferation in the presence of LH, IGF1 or a combined treatment of LH and IGF1 (Experiment 6). Treatments were applied for 48 h. Means \pm S.E.M. without a common letter differ $(P<0.05)$, and represent $n=9$ for each mean. 

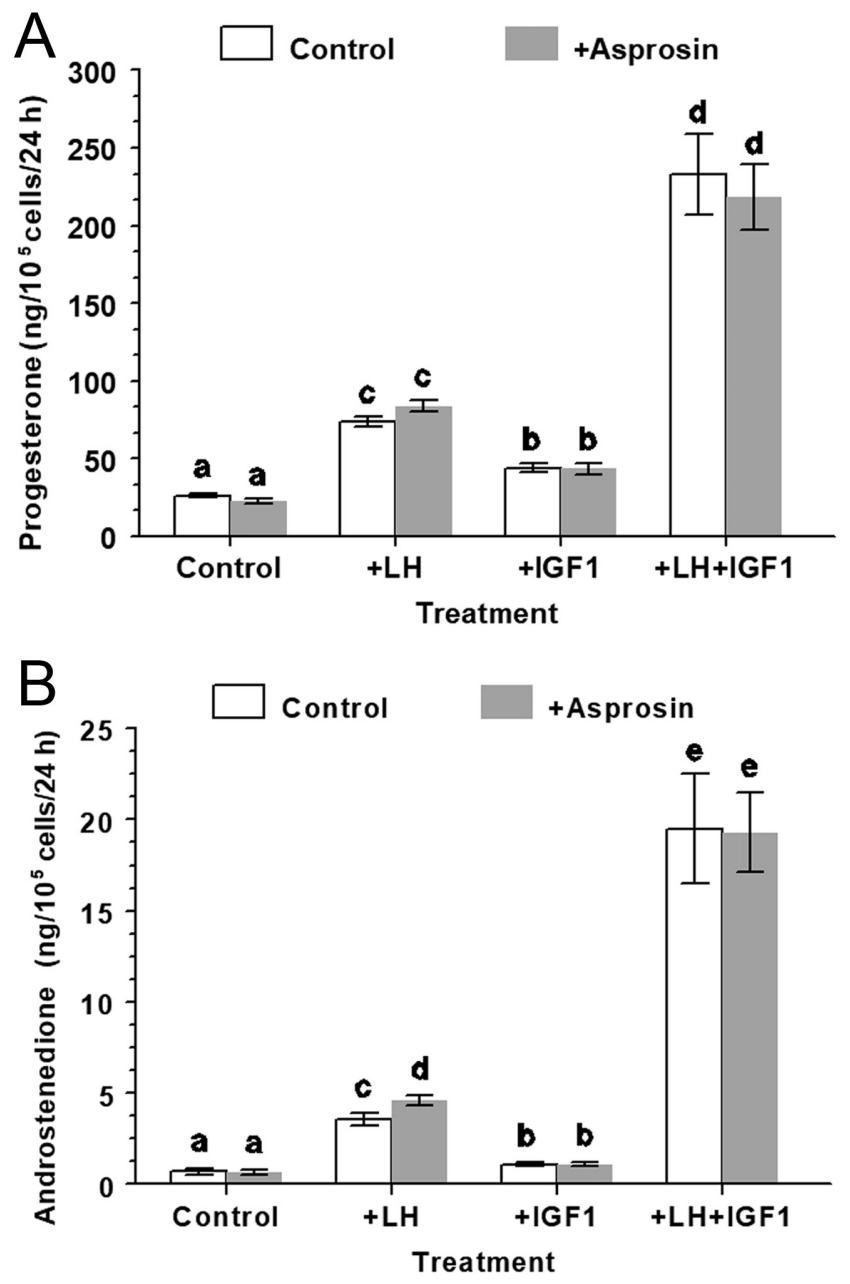

\section{Figure 6}

Effect of asprosin on LH- and IGF1-induced steroidogenesis in theca cells (TC) (Experiment 6). Panel A: Progesterone production in asprosin-treated, large-follicle TC concomitantly treated with LH, IGF1 or both. Means \pm S.E.M. without a common letter differ $(P<0.05)$. Panel B: Androstenedione production in asprosin-treated, large-follicle TC concomitantly treated with LH, IGF1 or both. Means \pm S.E.M. without a common letter differ $(P<0.05)$, and represent $n=9$ for each mean.

counterpart, asprosin in ovarian follicular function in mammals. The present studies revealed that (1) FBN1 mRNA abundance was greater in TC than GC, whereas, OR4M1 mRNA was greatest in SM-follicle GC; (2) FURIN mRNA abundance was greater in TC than GC but did not differ among follicle sizes; (3) TGFB1, EGF, FGF2 and FGF9 stimulated FBN1 mRNA abundance in TC whereas steroids (E2, A4, DHT and P4), leptin and insulin did not affect FBN1 mRNA abundance; and (4) asprosin enhanced LH-induced A4 production and inhibited IGF1-induced cell proliferation but did not affect $\mathrm{P} 4$ production.

Most hormones that are involved in the development of follicles from pre-antral to ovulatory size act via endocrine signaling (Jones \& Shikanov 2019), while growth factors (i.e. keratinocyte growth factor, hepatocyte growth factor, wingless signaling type factor, etc.) stimulate DNA synthesis in one cell type and promote a response in another (Monget \& Monniaux 1995, Robker \& Richards 1998, Palma et al. 2012). Within the follicle, these subsequent responses could generally stimulate or suppress cell proliferation, hormone release and/or oocyte maturation. Intrafollicular growth factors can be produced in TC and affect GC function, and vice versa (Monget \& Monniaux 1995, Nilsson et al. 2003). In the present study, abundance of FBN1, FURIN and OR4M1 mRNA differed between large and small follicles with FBN1 and FURIN mRNA being expressed mostly in TC, while OR4M1 mRNA was expressed more abundantly in SM-follicle GC. This may suggest a paracrine-autocrine signaling role for asprosin in ovarian follicles. It would be expected that asprosin would have greater effects in GC where OR4M1 mRNA is more abundantly expressed than in TC, but further studies will be required to verify this suggestion.

Previous research has shown that FBN1 is a structural protein that is present in the tunica albuginea, ovarian stroma and theca layers with major roles in the structural formation of microfibrils and as an environmental niche for growth factor signaling (Prodoehl et al. 2009, Sengle \& Sakai 2015). Fibrillin-1 protein has been localized in fetal and adult bovine ovaries, specifically an intense stain in the tunica albuginea and theca interna but lesser in the stroma (Rodgers et al. 2003, Hatzirodos et al. 2011). Similarly, FBN1 mRNA abundance was greatest in TC of the present study. The GC and TC communicationinteraction are important for the maintenance of follicular structure and function, like growth and differentiation of these cells (Skinner \& Coffey 1988, Nilsson et al. 2003, Tajima et al. 2007). Interestingly, FBN1 mRNA levels in TC were increased the greatest by TGFB1, and increased to a lesser extent by EGF and FGFs in the present study, whereas steroids, leptin, insulin and IGF1 had no effect on FBN1 expression, and IGF1 had little effect on asprosin action. Similarly, Bastian et al. (2016) reported that TGFB1 increased FBN1 mRNA in bovine fetal fibroblasts, whereas steroids and IGF1 had no effect, supporting findings of the present study. Also, in a tight-skin mouse model, TGFB1 stimulated FBN1 assembly (Lemaire et al. 2010), and in human dermal fibroblasts, TGFB1 induced FBN1 protein incorporation (Kissin et al. 2002). As a signaling protein, FBN1 regulates growth factor/cytokine activity by binding to latent TGFB1 binding proteins (LTBP) 1 to 4 and controls TGFB1 availability and function (Zilberberg et al. 
2012), is greater in stroma of adult than fetal bovine ovaries (Hatzirodos et al. 2011), and increases in fetal bovine ovarian stroma during gestation (Hatzirodos et al. 2019). Thus, ovarian FBN1 gene expression may function as a matrix protein as well as to provide an intraovarian source of asprosin. As mentioned earlier, elevated plasma asprosin levels in women are associated with increased risk for developing PCOS and correlated positively with free androgen index (Alan et al. 2019) and total testosterone in obese PCOS women ( $\mathrm{Li}$ et al. 2018), the latter of which is consistent with results of the present study where asprosin increased LH-induced A4 production by TC. However, FBN1 mRNA levels in ovarian stroma did not differ between PCOS and nonPCOS women (Prodoehl et al. 2009), suggesting further research is needed to clarify the relative contribution of systemic vs locally produced asprosin as a source of intraovarian asprosin. It is important to emphasize that attempts to use Western blotting to detect asprosin protein in GC and TC lysates in the present study were unsuccessful, most likely because of the small quantities of protein produced. Thus, additional developmental work will be required to ascertain if changes in cellular or secreted asprosin protein levels parallel FBN1 mRNA levels during follicular growth and atresia.

In the present study, asprosin increased LH-induced A4 production by TC providing the first evidence that asprosin has direct effects on ovarian follicular function. Interestingly, IGF1-induced TC proliferation was weakly inhibited by asprosin in the present study. Moreover, asprosin did not affect P4 production stimulated by IGF1 and $\mathrm{LH}$ treatments. In support of the present study, $\mathrm{Li}$ et al. (2018) found that plasma asprosin levels correlated positively with total testosterone levels in obese PCOS women but not normal-weight PCOS women, and asprosin levels did not significantly correlate with plasma progesterone or 17-OH-progesterone levels. The weak effects of asprosin on TC steroidogenesis and cell proliferation are reflected by low asprosin receptor expression (i.e. OR4M1 mRNA) observed in LG-follicle TC of Experiment 1. Nonetheless, the stimulatory effect of asprosin on A4 production and inhibitory effect on IGF1-induced cell proliferation suggests that asprosin may directly contribute to TC differentiation and thus asprosin may serve as a paracrine and/or autocrine regulator of ovarian function, but further research is required to confirm this. Future research should also evaluate if asprosin has direct effects on granulosa cell function.

\section{Declarations of interest}

The authors declare that there is no conflict of interest that could be perceived as prejudicing the impartiality of the research reported.

\section{Funding}

This research did not receive any specific grant from funding agencies in the public, commercial, or not-for-profits sectors.

\section{Acknowledgements}

The authors thank $\mathrm{H}$ Crenshaw, M Ellison, $\mathrm{K}$ Roof, and L Turenne for technical assistance; Dr A F Parlow, National Hormone and Pituitary Program (Torrance, CA) for purified LH; and Creekstone Farms for their generous donation of bovine ovaries. Approved for publication by the Director, Oklahoma Agric. Exp. Sta.

\section{References}

Alan M, Gurlek B, Yilmaz A, Aksit M, Aslanipour B, Gulhan I, Mehmet C \& Taner CE 2019 Asprosin: a novel peptide hormone related to insulin resistance in women with polycystic ovary syndrome. Gynecological Endocrinology 35 220-223. (https://doi.org/10.1080/095 13590.2018.1512967)

Bastian NA, Bayne RA, Hummitzsch K, Hatzirodos N, Bonner WM, Hartanti MD, Irving-Rodgers HF, Anderson RA \& Rodgers RJ 2016 Regulation of fibrillins and modulators of TGF $\beta$ in fetal bovine and human ovaries. Reproduction 152 127-137. (https://doi.org/10.1530/ REP-16-0172)

Dentis JL, Schreiber NB, Gilliam JN, Schutz LF \& Spicer LJ 2017 Changes in brain ribonuclease (BRB) mRNA in granulosa cells (GC) of dominant versus subordinate ovarian follicles of cattle and the regulation of BRB gene expression in bovine GC. Domestic Animal Endocrinology 55 32-40. (https://doi.org/10.1016/j. domaniend.2015.10.008)

Duerrschmid C, He Y, Wang C, Li C, Bournat JC, Romere C, Saha PK, Lee ME, Phillips KJ, Jain M, et al. 2017 Asprosin is a centrally acting orexigenic hormone. Nature Medicine 23 1444-1453. (https://doi. org/10.1038/nm.4432)

Hatzirodos N, Bayne RA, Irving-Rodgers HF, Hummitzsch K, Sabatier L, Lee S, Bonner W, Gibson MA, Rainey WE, Carr BR, et al. 2011 Linkage of regulators of TGF- $\beta$ activity in the fetal ovary to polycystic ovary syndrome. FASEB Journal 25 2256-2265. (https:// doi.org/10.1096/fj.11-181099)

Hatzirodos N, Hummitzsch K, Irving-Rodgers HF, Breen J, Perry VEA, Anderson RA \& Rodgers RJ 2019 Transcript abundance of stromal and thecal cell related genes during bovine ovarian development. PLOS ONE 14 e0213575. (https://doi.org/10.1371/journal. pone.0213575)

Hoffmann JG, Xie W \& Chopra AR 2020 Energy regulation mechanism and therapeutic potential of asprosin. Diabetes $69559-566$. (https:// doi.org/10.2337/dbi19-0009)

Hsueh AJW, Kawamura K, Cheng Y \& Fause BCJM 2015 Intraovarian control of early folliculogenesis. Endocrine Reviews 36 1-24. (https:// doi.org/10.1210/er.2014-1020)

Jones ASK \& Shikanov A 2019 Follicle development as an orchestrated signaling network in a 3D organoid. Journal of Biological Engineering 13 2. (https://doi.org/10.1186/s13036-018-0134-3)

Kissin EY, Lemaire R, Korn JH \& Lafyatis R 2002 Transforming growth factor beta induces fibroblast fibrillin-1 matrix formation. Arthritis and Rheumatism 46 3000-3009. (https://doi.org/10.1002/art.10621) 
Langhout DJ, Spicer LJ \& Geisert RD 1991 Development of a culture system for bovine granulosa cells: effects of growth hormone, estradiol, and gonadotropins on cell proliferation, steroidogenesis, and protein synthesis. Journal of Animal Science $693321-3334$ (https://doi.org/10.2527/1991.6983321x)

Lemaire R, Farina G, Bayle J, Dimarzio M, Pendergrass SA, Milano A, Perbal B, Whitfield ML \& Lafyatis R 2010 Antagonistic effect of the matricellular signaling protein CCN3 on TGF-beta- and Wntmediated fibrillinogenesis in systemic sclerosis and Marfan syndrome. Journal of Investigative Dermatology 130 1514-1523. (https://doi.org/10.1038/jid.2010.15)

Li X, Liao M, Shen R, Zhang LK, Hu H, Wu J, Wang X, Qu H, Guo S, Long M, et al. 2018 Plasma asprosin levels are associated with glucose metabolism, lipid and sex hormone profiles in females with metabolic-related diseases. Mediators of Inflammation 20187375294. (https://doi.org/10.1155/2018/7375294)

Li E, Shan H, Chen L, Long A, Zhang Y, Liu Y, Jia L, Wei F, Han J, Li T, et al. 2019 OLFR734 mediates glucose metabolism as a receptor of asprosin. Cell Metabolism 30 319.e8-328.e8. (https://doi. org/10.1016/j.cmet.2019.05.022)

Liu YX, Zhang Y, Li YY, Liu XM, Wang XX, Zhang CL, Hao CF \& Deng SL 2019 Regulation of follicular development and differentiation by intra-ovarian factors and endocrine hormones. Frontiers in Bioscience 24 983-993.

Meng TG, Hu MW, Ma XS, Huang L, Liang QX, Yuan Y, Hou Y, Wang H, Schatten H, Wang ZB, et al. 2017 Oocyte-specific deletion of furin leads to female infertility by causing early secondary follicle arrest in mice. Cell Death and Disease 8 e2846. (https://doi.org/10.1038/ cddis.2017.231)

Monget P \& Monniaux D 1995 Growth factors and the control of folliculogenesis. Journal of Reproduction and Fertility. Supplement 49 321-333. (https://doi.org/10.1530/biosciprocs.3.025)

Morrell BC, Perego MC, Maylem ERS, Zhang L, Schütz LF \& Spicer LJ 2020 Regulation of the transcription factor E2F1 mRNA in ovarian granulosa cells of cattle. Journal of Animal Science 98 1-8. (https:// doi.org/10.1093/jas/skz376)

Nilsson EE, Doraiswamy V \& Skinner MK 2003 Transforming growth factor-beta isoform expression during bovine ovarian antral follicle development. Molecular Reproduction and Development 66 237-246. (https://doi.org/10.1002/mrd.10350)

Palma GA, Argañaraz ME, Barrera AD, Rodler D, Mutto AÁ \& Sinowatz F 2012 Biology and biotechnology of follicle development. Thescientificworldjournal 2012938138 . (https://doi. org/10.1100/2012/938138)

Pizzo F, Caloni F, Schutz LF, Totty ML \& Spicer LJ 2015 Individual and combined effects of deoxynivalenol and $\alpha$-zearalenol on cell proliferation and steroidogenesis of granulosa cells in cattle. Environmental Toxicology and Pharmacology 40 722-728. (https://doi. org/10.1016/j.etap.2015.08.025)

Pizzo F, Caloni F, Schreiber NB, Cortinovis C \& Spicer LJ 2016 In vitro effects of deoxynivalenol and zearalenone major metabolites alone and combined, on cell proliferation, steroid production and gene expression in bovine small-follicle granulosa cells. Toxicon $\mathbf{1 0 9}$ 70-83. (https://doi.org/10.1016/j.toxicon.2015.11.018)

Prodoehl MJ, Irving-Rodgers HF, Bonner WM, Sullivan TM, Micke GC, Gibson MA, Perry VE \& Rodgers RJ 2009 Fibrillins and latent TGF $\beta$ binding proteins in bovine ovaries of offspring following high or low protein diets during pregnancy of dams. Molecular and Cellular Endocrinology 307 133-141. (https://doi.org/10.1016/j. mce.2009.03.002)

Richards JS, Ren YA, Candelaria N, Adams JE \& Rajkovic A 2018 Ovarian follicular theca cell recruitment, differentiation, and impact on fertility: 2017 update. Endocrine Reviews 39 1-20. (https://doi. org/10.1210/er.2017-00164)

Robker RL \& Richards JS 1998 Hormonal control of the cell cycle in ovarian cells: proliferation versus differentiation. Biology of
Reproduction 59 476-482. (https://doi.org/10.1095/ biolreprod59.3.476)

Rodgers RJ, Irving-Rodgers HF \& Russell DL 2003 Extracellular matrix of the developing ovarian follicle. Reproduction 126 415-424. (https:// doi.org/10.1530/rep.0.1260415)

Romere C, Duerrschmid C, Bournat J, Constable P, Jain M, Xia F, Saha PK, Del Solar M, Zhu B, York B, et al. 2016 Asprosin, a fastinginduced glucogenic protein hormone. Cell 165 566-579. (https://doi. org/10.1016/j.cell.2016.02.063)

Rosenfield RL \& Ehrmann DA 2016 The pathogenesis of polycystic ovary syndrome (PCOS): the hypothesis of PCOS as functional ovarian hyperandrogenism revisited. Endocrine Reviews 37 467-520. (https://doi.org/10.1210/er.2015-1104)

Schmittgen TD \& Zakrajsek BA 2000 Effect of experimental treatment on housekeeping gene expression: validation by real-time, quantitative RT-PCR. Journal of Biochemical and Biophysical Methods 46 69-81. (https://doi.org/10.1016/s0165-022x(00)00129-9)

Schreiber NB \& Spicer LJ 2012 Effects of fibroblast growth factor 9 (FGF9) on steroidogenesis and gene expression and control of FGF9 mRNA in bovine granulosa cells. Endocrinology 153 4491-4501. (https://doi.org/10.1210/en.2012-1003)

Schreiber NB, Totty ML \& Spicer LJ 2012 Expression and effect of fibroblast growth factor 9 in bovine theca cells. Journal of Endocrinology 215 167-175. (https://doi.org/10.1530/JOE-12-0293)

Schütz LF, Schreiber NB, Gilliam JN, Cortinovis C, Totty ML, Caloni F, Evans JR \& Spicer LJ 2016 Changes in fibroblast growth factor 9 mRNA in granulosa and theca cells during ovarian follicular growth in dairy cattle. Journal of Dairy Science 99 9143-9151. (https://doi. org/10.3168/jds.2015-10667)

Sekar N, Garmey JC \& Veldhuis JD 2000 Mechanisms underlying the steroidogenic synergy of insulin and luteinizing hormone in porcine granulosa cells: joint amplification of pivotal sterolregulatory genes encoding the low-density lipoprotein (LDL) receptor, steroidogenic acute regulatory (stAR) protein and cytochrome P450 side-chain cleavage (P450scc) enzyme. Molecular and Cellular Endocrinology 159 25-35. (https://doi.org/10.1016/ s0303-7207(99)00203-8)

Sengle G \& Sakai LY 2015 The fibrillin microfibril scaffold: a niche for growth factors and mechanosensation? Matrix Biology 47 3-12. (https://doi.org/10.1016/j.matbio.2015.05.002)

Skinner MK \& Coffey RJJ 1988 Regulation of ovarian cell growth through the local production of transforming growth factor-alpha by theca cells. Endocrinology 123 2632-2638. (https://doi.org/10.1210/ endo-123-6-2632)

Spicer LJ 2005 Effects of estradiol on bovine thecal cell function in vitro: dependence on insulin and gonadotropins. Journal of Dairy Science 88 2412-2421. (https://doi.org/10.3168/jds.S00220302(05)72919-2)

Spicer LJ \& Stewart RE 1996 Interactions among basic fibroblast growth factor, epidermal growth factor, insulin, and insulin-like growth factor-I (IGF-I) on cell numbers and steroidogenesis of bovine thecal cells: role of IGF-I receptors. Biology of Reproduction 54 255-263. (https://doi.org/10.1095/biolreprod54.1.255)

Spicer LJ, Aad PY, Allen D, Mazerbourg S \& Hsueh AJ 2006 Growth differentiation factor-9 has divergent effects on proliferation and steroidogenesis of bovine granulosa cells. Journal of Endocrinology 189 329-339. (https://doi.org/10.1677/joe.1.06503)

Stewart RE, Spicer LJ, Hamilton TD \& Keefer BE 1995 Effects of insulinlike growth factor I and insulin on proliferation and on basal and luteinizing hormone-induced steroidogenesis of bovine thecal cells: involvement of glucose and receptors for insulin-like growth factor I and luteinizing hormone. Journal of Animal Science 73 3719-3731. (https://doi.org/10.2527/1995.73123719x)

Tajima K, Orisaka M, Mori T \& Kotsuji F 2007 Ovarian theca cells in follicular function. Reproductive Biomedicine Online 15 591-609. (https://doi.org/10.1016/s1472-6483(10)60392-6) 
Tsuji N, Kamagata C, Furuya M, Kobayashi D, Yagihashi A, Morita T, Horita S \& Watanabe N 2002 Selection of an internal control gene for quantitation of mRNA in colonic tissues. Anticancer Research 22 4173-4178.

Voge JL, Aad PY, Santiago CA, Goad DW, Malayer JR, Allen DT \& Spicer LJ 2004 Effect of insulin-like growth factors (IGF), FSH, and leptin on IGF-binding-protein mRNA expression in bovine granulosa and theca cells: quantitative detection by real-time PCR. Peptides 25 2195-2203. (https://doi.org/10.1016/j. peptides.2004.07.008)

Wang Y, Qu H, Xiong X, Qiu Y, Liao Y, Chen Y, Zheng Y \& Zheng H 2018 Plasma asprosin concentrations are increased in individuals with glucose dysregulation and correlated with insulin resistance and first-phase insulin secretion. Mediators of Inflammation 2018 9471583. (https://doi.org/10.1155/2018/9471583)

Wang M, Yin C, Wang L, Liu Y, Li H, Li M, Yi X \& Xiao Y 2019 Serum asprosin concentrations are increased and associated with insulin resistance in children with obesity. Annals of Nutrition and Metabolism 75 205-212. (https://doi.org/10.1159/000503808)

Yada H, Hosokawa K, Tajima K, Hasegawa Y \& Kotsuji F 1999 Role of ovarian theca and granulosa cell interaction in hormone production and cell growth during the bovine follicular maturation process. Biology of Reproduction 61 1480-1486. (https://doi.org/10.1095/ biolreprod61.6.1480)

Young JM \& McNeilly AS 2010. Theca: the forgotten cell of the ovarian follicle. Reproduction 140 489-504. (https://doi.org/10.1530/REP-10-0094)

Zhang L, Schütz LF, Robinson CL, Totty ML \& Spicer LJ 2017 Evidence that gene expression of ovarian follicular tight junction proteins is regulated in vivo and in vitro in cattle. Journal of Animal Science $\mathbf{9 5}$ 1313-1324. (https://doi.org/10.2527/jas.2016.0892)

Zilberberg L, Todorovic V, Dabovic B, Horiguchi M, Couroussé T, Sakai LY \& Rifkin DB 2012 Specificity of latent TGF- $\beta$ binding protein (LTBP) incorporation into matrix: role of fibrillins and fibronectin. Journal of Cellular Physiology 227 3828-3836. (https://doi.org/10.1002/jcp.24094)

Received in final form 8 October 2020

Accepted 20 October 2020

Accepted Manuscript published online 20 October 2020
(C) 2021 Society for Endocrinology Published by Bioscientifica Ltd. Printed in Great Britain 